\title{
Heavy mental workload increase poor sleep quality in informal garment workers
}

\author{
Lie T. Merijanti S*, Pusparini**, Meiyanti***, Alvina**, \\ Novia I Sudharma ${ }^{\dagger}$, and Muljadi Tjahjadi
}

\begin{abstract}
\section{BACKGROUND}

Sleep is needed by the human body so that the performance of body remains optimal when the body is awake, especially during work. Informal workers often work without clear regulations, with inadequate equipment and poor work environment, and pay little attention to occupational health and safety factors. The existence of large work demands with unclear work system arrangements will certainly result in a mental workload in these workers. The objective of this study was to determine the relationship between mental workload and sleep patterns of workers in the informal garment sector.
\end{abstract}

\section{METHODS}

A cross-sectional study involving 225 informal garment workers was conducted between December 2018 and May 2019. Data collection included respondents' demographics, job characteristics, measurement of mental burden and disturbances in sleep patterns. The sleep pattern used the PSQI (Pittsburgh Sleep Quality Index) instrument and the mental burden used the Rating Scale Mental Effort (RSME). A multiple linear regression analysis was used to analyze the data.

\section{RESULTS}

The mean sleep quality was $5.40 \pm 2.54$. Multiple linear regression test found that mental workload correlated significantly with sleep quality of workers $(\beta=0.016, p=0.012)$.

\section{CONCLUSION}

This study demonstrated that heavy mental workload decreases the quality of sleep in informal garment workers. A good work system management is required so that workers are assigned that portion of the task that is commensurate with their capacity.

Keywords: Mental workload, informal garment workers, sleep quality
*Department of Occupational

Medicine, Medical Faculty,

Trisakti University

**Department of Clinical Pathology,

Trisakti University

***Department of Pharmacy,

Trisakti University

$\dagger$ Department of Public Health, Medical Faculty, Trisakti University

†Center of Education and Training,

Ministry of Industry Indonesia

Republic of Indonesia

\section{Correspondence:}

Lie T Merijanti S, dr. MKK

Department of Occupational Medicine, Faculty of Medicine,

Trisakti University

Jl. Kyai Tapa No 260 Grogol,

Jakarta 11440

Phone: 021-5672731 ext 2802

Email: liemerijanti@trisakti.ac.id

Orcid ID : 0000-0001-8203-0753

Date of first submission, September 18, 2019

Date of final revised submission,

December 18, 2019

Date of acceptance, December 19, 2019

This open access article is distributed under a Creative Commons AttributionNon Commercial-Share Alike 4.0 International License

Cite this article as: Merijanti LT, Pusparini, Meiyanti, Alvina, Sudharma NI, Tjahjadi M. Heavy mental workload increase poor sleep in informal garment workers. UnivMed 2019;38:202-8. doi: 10.18051/UnivMed.2019.v38.202-208 


\section{INTRODUCTION}

Sleep is needed by the human body so that the performance of the body remains optimal when awake, especially during work. During sleep, the body will form and regenerate its cells, support brain function, and replenish bodily energy. Sleep quality is an important clinical construct for being healthy. Poor sleep quality can be an important symptom of many sleep disorders and other medical diseases and may even directly lead to increased mortality. ${ }^{(1)}$ Workers with a sleep duration of less than five hours will experience more stress than do those with an adequate sleep duration. There is a greater awareness of high stress in younger workers, specialized workers, office workers and those with mid-high household income. ${ }^{(2)}$

The Centers for Disease Control and Prevention, after an analysis of the data from the Behavioral Risk Factor Surveillance System (BRFSS) for the years 2013 and 2014 in 29 states of the USA, found that the highest prevalence of inadequate sleep duration was in production workers and health personnel. ${ }^{(3)}$ Sleep disorders cause the loss of 1.2 million workdays, so that it is estimated that for each worker who has less than six hours of sleep, a total of 226 US dollars must be added to the US economic budget. ${ }^{(4)}$ Sleep deprivation and drowsiness are the workers' main health problems that may result in increased morbidity, work-related errors, occupational accidents, absenteeism, and decreased work productivity. ${ }^{(1,2)}$

The precipitating factors of sleep disorders may arise from the work environment, such as the shift work system, work requirements or workloads, and also from individual factors, such as age, gender, life style, current illness, inadequate resting time on workdays, and family and social environment, such as marital status and activities of daily living. ${ }^{(5,6)}$

In the modern worker's life, there is increased work insecurity and mental workload. Mental workload is a set of factors that affect the mental processing of information, providing decision making and individual reactions in the workplace. ${ }^{(7)}$ A study involving 656 US students showed that a higher mental workload is associated with lower overall sleep quality. ${ }^{(8)} \mathrm{A}$ study on 243 healthcare office workers indicated that mental workload is significantly associated with sleep quality. ${ }^{(9)}$ A Japanese study on 5951 male and 1500 female government office workers found that the gender difference in insomnia depended on the type of work and the family characteristics of the workers themselves, where significant gender differences in insomnia were not found among shift workers, subjects engaged in $6 \mathrm{~h}$ per day or more of VDT work, those with high job strain, those who did household tasks for $1 \mathrm{~h}$ per day or more, and those living with persons who needed care and support. ${ }^{(10)}$ In Indonesia, a study on 259 firemen found 111 persons $(42.9 \%)$ with insomnia associated with excessive qualitative and quantitative workloads and residential areas near sources of noise. ${ }^{(11)}$

Heavy workloads, in addition to a delay of sleep onset, also cause a homeostatic sleep response by increasing subjective fatigue and drowsiness, and reducing the time of awakening after sleep. ${ }^{(12)}$ Individuals with a constant heavy workload will have a poorer sleep quality than workers with a low/moderate workload. However, the sleep quality does not decrease and work-related perseverative cognition does not increase over time for individuals experiencing stable high job demands. ${ }^{(13)}$

According to the Indonesian Central Bureau of Statistics, there are in total 73.98 million (58.22\%) informal workers and 41.78 million formal workers. Of 127.07 million working persons, $7.64 \%$ are categorized as semiunemployed and $23.83 \%$ are part-time workers. ${ }^{(14)}$ Previous studies have more frequently focused on formal sector workers, and there is a lack of information on studies involving informal workers. The present study aimed to determine the relationship between mental workload on sleep quality in informal garment workers. 


\section{METHODS}

\section{Design of the study}

This observational cross-sectional study was conducted in one village (kelurahan) of West Jakarta, from December 2018 to May 2019.

\section{Study subjects}

The study subjects were informal garment workers from one kelurahan of West Jakarta who met the inclusion criteria and agreed to participate in the study. The exclusion criteria were: persons with affective disorders (depression), anxiety, or chronic disease and those consuming antidepressants, narcotics, diuretics, beta blockers, or caffeine. The required sample size was calculated using the formula for the sample size of a cross-sectional study, with $\alpha$ of 0.05 , prevalence of poor sleep quality of $42.9 \%$ (15) and anticipated drop-out of $10 \%$, yielding a total of 225 workers. The subjects were selected by consecutive sampling and all subjects signed an informed consent form.

\section{Data collection}

Data were collected using three questionnaires as assessment instruments, namely a demographic characteristics questionnaire, the Rating Scale Mental Effort (RSME) questionnaire for mental workload, and the Pittsburgh Sleep Quality Index (PSQI) questionnaire for sleep quality.

The demographic questionnaire comprised questions such as gender, age, education, type of employment, work duration (work period), length of employment, resting time and work wages. The Pittsburgh Sleep Quality Index (PSQI), developed in 1989 by Buysse and coworkers, ${ }^{(16)}$ has seven domains for evaluating sleep quality or sleep degradation during one month. The domains are subjective sleep quality, sleep latency, sleep duration, habitual sleep efficiency, sleep disturbances, use of sleep medications and daytime dysfunction. The total PSQI score has a value of 0 to 21 , being the sum of the point values for the seven domains, each question yielding point values of 0 to 3 . High scores indicate bad sleep quality and low scores indicate adequate sleep quality. A person with a total score of more than 5 has a clinically poor sleep quality. The PSQI has been used successfully in a recent study. ${ }^{(17)}$ The mental workload is evaluated subjectively by constructing a psychometric scale to measure the mental workload based on the worker's or respondent's subjective perception, using the Rating Scale Mental Effort (RSME) instrument, in which the respondent is asked to evaluate his or her effort to complete the assigned work on a scale of $0-150$, the score of 0 indicating no effort whatsoever and the score of 150 indicating extreme effort. ${ }^{(18)}$

\section{Statistical analysis}

The data were entered, coded, processed and analyzed using SPSS version 21 . The results of the test on normality of the data showed that the collected data were normally distributed. For the categorical variables, the frequency and percentage was calculated, whereas continuous variables were summarized using the mean and standard deviation and analyzed by multiple linear regression. A $p$ value of $<0.05$ was considered statistically significant.

\section{Ethical clearance}

This study received ethical clearance from the Commission on Research Ethics, Faculty of Medicine, Trisakti University, under no. 139/ KER/FK.

\section{RESULTS}

The respondents were informal garment workers, comprising 136 males $(60.4 \%)$ with mean age of $33.31 \pm 11.14$ years. The education of the workers was predominantly elementary school (48.4\%) and junior high school (40\%), with mean RSME of $79.64 \pm 27.55$, and mean PSQI of $79.64 \pm 27.55$ (Table 1).

Table 2 above of the results of the multiple linear regression analysis shows that mental 
Table 1. Distribution of demographics, work characteristics, RSME, and PSQI of the respondents $(n=225)$

\begin{tabular}{lc}
\hline Variable & $\mathbf{n}(\mathbf{\%})$ \\
\hline Gender & $136(60.4 \%)$ \\
Male & $89(39.6 \%)$ \\
Female & $33.31 \pm 11.14$ \\
Age (years) & \\
Education & $109(48.4 \%)$ \\
Elementary school & $90(40 \%)$ \\
Junior high school & $26(11.6 \%)$ \\
Senior high school & \\
Work unit & $137(60.9 \%)$ \\
Manual sewing & $6(2.7 \%)$ \\
Cutting & $22(9.8 \%)$ \\
Piping & $3(1.3 \%)$ \\
Overlock machine sewing & $32(14.2 \%)$ \\
Thread trimming & $7(3.1 \%)$ \\
Ironing & $18(8 \%)$ \\
Finishing & $8.047 \pm 7.74$ \\
Length of employment (years) & $11.413 \pm 1.99$ \\
Work duration per working day (hours) & $1.18 \pm 0.44$ \\
Resting time during work (hours) & \\
Wages & $79(35.1 \%)$ \\
Rp 200.000 - 500.000/week & $146(64.9 \%)$ \\
Rp 600.000 - 1.000.000/week & $143(63.6 \%)$ \\
Occupational accident & $82(36.4 \%)$ \\
Ever & $79.64 \pm 27.55$ \\
Never & $5.40 \pm 2.54$ \\
RSME & \\
PSQI & \\
\hline
\end{tabular}

Data presented as $\mathrm{n}(\%)$ except for age, length of employment, work duration per day, RSME and PSQI (as mean \pm SD)

workload is significantly associated with sleep quality, but gender and age are not significantly associated $(\beta=0.016 ; p=0.012)$.

\section{DISCUSSION}

Our study results showed that heavy mental workload reduced sleep quality in informal garment workers. Psychological occupational hazards such as long work duration, heavy mental workload, inadequate work control, inadequate wages, discomfort during work and problems in regulation of work organization, are associated with increased sleep disorders in workers throughout the world, potentially causing various cardiovascular, cerebrovascular and mental health disorders among the workers. ${ }^{(19)}$ Heavy mental workloads and long work duration interferes with health and causes the workers to leave the workplace. $^{(20)}$
According to the present study there was a positive correlation between performance/work results and drowsiness, so that this should become a matter for consideration of the work assignment to be given, and the specific capacity of workers in completing the work, because of its individual nature. If the workers are incapable of completing the assignment then there will be a cumulative physical work fatigue in the form of reduced capacity of the muscular system and mental fatigue in the form of reduced alertness. ${ }^{(21)}$ In

Table 2. Multiple linear regression between occupational variables and sleep quality

\begin{tabular}{lcc}
\hline Respondent's characteristic & $\boldsymbol{\beta}$ & $\mathbf{p}$ \\
\hline Gender & -0.268 & 0.477 \\
Age & -0.004 & $0.83 \mathrm{C}$ \\
Work duration & 0.085 & $0.35 \mathrm{C}$ \\
Length of employment & -0.006 & $0.82 \mathrm{C}$ \\
Resting time & -0.094 & $0.80 \mathrm{C}$ \\
RSME & 0.016 & 0.012 \\
Occupational accident & 0.169 & 0.644 \\
\hline
\end{tabular}


the present study it can be seen that with the large reported number of cases of occupational accident, where 143 workers (63.6\%) ever had an occupational accident, but the results of the analysis did not show a significant association with the sleep quality of the workers.

The majority of the workers had extremely long working hours of more than 8 hours per day, so that they worked until late in the night, which if occurring continually, will interfere with the body's circadian rhythm, such as disturbing the sleep pattern. Continual physical activity during work causes musculoskeletal pain and interferes with sleep. ${ }^{(22)}$

A different study showed that older workers do not have sleep problems with the passage of time, in contrast with younger workers. Aging has a positive effect on the occurrence of fatigue and sleep, both of which are related, where the need for sleep decreases with age. ${ }^{(23,24)}$

From the results of multiple linear regression analysis, the characteristic of the respondents, in this case gender in relation to sleep quality, turned out to be not significantly associated. Similar results were found in a Japanese study, where the effect of gender on the occurrence of sleep disorder is also influenced by the shift work system, computerrelated work, household work, and care for the family, that must be performed more by women, in comparison with the biological differences between males and females. ${ }^{(10)}$ Another study obtained different results, where women showed decreased sleep quality, possibly caused by high sensitivity to psychosocial stress and changes in the body's circadian rhythm. ${ }^{(24)} \mathrm{A}$ study on hospital nurses in China found that sleep disorder is statistically associated with gender, age, work duration, and night shift. ${ }^{(9)}$

The high degree of stress will decrease sleep quality due to increased sleep disturbance and interference with activities of daily living. ${ }^{(25)}$ The role of polymorphism of the receptor gene 5-HTR2A is also associated an individual's sleep quality, and will add to the cumulative effect on sleep quality. ${ }^{(26)}$ Work load increases the risk of poor sleep quality, ${ }^{(9)}$ and its effect will be worse in workers with a specific gene polymorphism. ${ }^{(23)}$ Low sleep quality was significantly associated with lower morning cortisol secretion. While job strain had no main effects on the cortisol reactivity there was a significant interaction effect between the input variables on morning cortisol secretion. These findings tentatively support the hypothesis that lack of sleep for workers with high job strain may result in a flattened diurnal cortisol reactivity. ${ }^{(27)}$ However, other studies state that sleep quality does not decrease and work-related perseverative cognition did not increase over time for individuals experiencing stable high job demands. (13) The Swedish Longitudinal Occupational Survey of Health states that the findings of this cross-lagged analysis indicate a weak effect of demands on later sleep disturbances, an effect of sleep disturbances on later ratings on social support, and reciprocal relationship between awakening problems and work characteristics, they suggests that there are reverse and reciprocal causal relationships, in addition to associations in the usually hypothesized direction, between work characteristics and sleep problems based on a 2 -year time lag. ${ }^{(27)}$ A decrease of $25 \%$ of weekly work duration without reducing work pay, had positive benefits on increase in sleep duration, reduced drowsiness and incidence of stress during work days and holidays. ${ }^{(28)}$ The work condition should be improved and mental workloads should be adjusted so as to not disrupt their sleep status. ${ }^{(6)}$

This study has several limitations, firstly, the cross-sectional design of the study did little to describe the cause-and-effect relationship between mental workload and sleep disorder. Secondly, the measurement of mental workload and sleep quality was subjective, although RSME is a good index to evaluate the mental workload because of its acceptable correlation with another such as NASA TLX (Task Load index). ${ }^{(29)}$ PSQI reflects mainly sleep quality on workdays. ${ }^{(30)}$ Further studies using objective 
measurements of sleep quality could be a next step to understand how these relationships are intertwined. Additionally, studies on sleep disorders of workers that investigate how sleep quality differs on workdays when compared with work-free days might help us to understand how these patterns might be clinically relevant. Finally, this understanding might foster purposeful solutions to improve sleep quality and health.

\section{CONCLUSIONS}

This study found that heavy mental workload increases poor sleep quality in informal garment workers. To improve the health and productivity of the workers, requires the education and the realization of both the workers and the proprietors in the informal sector about adequate sleep for the workers.

\section{CONFLICT OF INTEREST}

There was no conflict of interest between both the investigators and the respondents in the conduct of this study.

\section{ACKNOWLEDGMENTS}

The investigators express their utmost gratitude to all parties who provided aid and assistance in the course of this study, to the Trisakti University as funding provider, to the proprietors of home industries and all respondents who participated up to the completion of this study.

\section{CONTRIBUTORS}

LTM contributed to the study design. LTM and $\mathrm{P}$ contributed to the construction of the questionnaire. LTM, P, M, A,N, MT contributed to recruitment of the subject sample and data collection. LTM and N performed analysis and data analysis. LTM and MT contributed to writing of the manuscript of this study. All authors read and approved the final manuscript.

\section{REFERENCES}

1. Yazdi Z, Sadeghniiat-Haghighi K, Loukzadeh Z, Elmizadeh K, Abbasi M. Prevalence of sleep disorders and their impacts on occupational performance: A comparison between shift workers and non-shift workers. Sleep Disorders 2014:1-5. http://dx.doi.org/10.1155/2014/870320.

2. Choi DW, Chun SY, Lee SA, Han KT, Park EC. Association between sleep duration and perceived stress: Salaried worker in circumstances of high workload. Int J Environ Res Public Health 2018;15,796:1-11 doi:10.3390/ijerph15040796.

3. Shockey TM, Wheaton AG. Short sleep duration by occupation group - 29 states, 2013-2014. US Department of Health and Human Service/Centers for Disease Control and Prevention. MMWR 2017;66:207-13.

4. Hafner M, Stepanek M, Taylor J, Troxel WM, van Stolket C. Why sleep matters - the economic costs of insufficient sleep: a cross-country comparative analysis. Santa Monica, CA: RAND Corporation; 2016.

5. Rifa'i FG, Martiana T. Hubungan antara stressor kerja dengan insomnia pada pekerja bergilir bagian central processing area di job $\mathrm{P}$-PEJ Tuban. Indonesian J Occup Safety Health 2014;3:35-45.

6. Yaylak D, Calýpgan B, Karakas T, et al. Heavy workload of nurses and effects of it on sleep / rested levels. TMSJ 2014; 23-26.

7. Malekpour F, Mohammadian Y, Malekpour AR, Mohammadpour Y, et al. Assessment of mental workload in nursing by using NASA-TLX. Journal of Urmia Nursing and Midwifery Faculty 2014;11:892-9.

8. Jansen EC, Peterson KE, O’Brien L, Hershner S, Boolani A. Associations between mental workload and sleep quality in a sample of young adults recruited from a US college town. Behav Sleep Med 2019;20:1-10. doi: 10.1080/ 15402002.2019.1626728.

9. Heidarimoghadam R, Saidnia H, Joudaki J, Mohammadi Y, Babamiri M. Does mental workload can lead to musculoskeletal disorders in office workers? Suggest and investigate a path. Cogent Psychol 2019;6:1-8. http://dx.doi.org/ 10.1080/23311908.2019.1664205.

10. Yoshioka E, Saijo Y, Kita T, etal. Gender differences in insomnia and the role of paid work and family responsibilities. Soc Psychiatry Psychiatr Epidemiol 2012;47:651-62. DOI: 10.1007/s00127011.0370-2

11. Afrianti R, Widyahening IS, Amri Z, Kusumawardhani A. Stresor kerja dan insomnia 
pada petugas pemadam kebakaran di Jakarta Selatan. J Indon Med Assoc 2011;6:487-92.

12. Goel N, Abe T, Braun ME, Dinges DF. Cognitive workload and sleep restriction interact to influence sleep homeostatic responses. Sleep 2014;37:174556.pii:sp-00060-14. http://dx.doi.org/10.5665/ sleep.4164.

13. van Laethem M, Beckers DGJ, Geurts SAE, Garefelt J, Hanson LLM, Leineeber C. Perseverative cognition as an explanatory mechanism in the relation between job demands and sleep quality. Int J Behav Med 2018;25:23142. DOI: 10.1007/s12529-017-9683-y.

14. Badan Pusat Statistik. Keadaan ketenagakerjaan Indonesia No 42/05/Th.XXI,07. Jakarta: Biro Pusat Statistik;2018.

15. Han Y, Yuan Y, Zhang L, Fu Y. Sleep disorder status of nurses in general hospitals and its influencing factors. Psychiatr Danub 2016;28: 176-83.

16. Buysse DJ, Reynolds CF, Monk TH. The Pittsburgh Sleep Quality Index: a new instrument for psychiatric practice and research. Psychiatry Res 1989;28:193-213.

17. Kühnel J, Bledow R, Feuerhahn N. When do you procrastinate? Sleep quality and social sleep lag jointly predict self-regulatory failure at work. J Organ Behav 2016;37:983-1002.

18. Johnson A, Widyanti A. Cultural influences on the measurement of subjective mental workload. Ergonomics 2011;54:509-18. https://doi.org/ 10.1080/00140139.2011.570459.

19. Härmä M. Psychosocial work characteristics and sleep - a well-known but poorly understood association. Scand J Work Environ Health 2013;39:531-3. Doi.10.5271/sjweh.3389.

20. Bos JT, Donders NCGM, van der Velden K, van der Gulden JWJ. Perceptions of mental workload in Dutch university employees of different ages: a focus group study. BMC Research Notes 2013;6:102. doi:10.1186/1756-0500-6-102.

21. Arellano JLH, Martínez JAC, Pérez JNS, Alcaraz JLG. Relationship between workload and fatigue among Mexican assembly operators. Int J Phys Med Rehabil 2015,3:1-6. DOI: 10.4172/23299096.1000315 .
22. Åkerstedt T, Discacciati A, Habel H, Westerlundz H. Psychosocial work demands and physical workload decrease with ageing in blue collar and white collar workers: a prospective study based on the SLOSH cohort. BMJ Open 2019;9:e030918. Doi: 10.1136/bmjopen-2019-030918.

23. Åkerstedt T, Discacciati A, Miley-Åkerstedt A, Westerlundz H. Aging and the change in fatigue and sleep- A longitudinal study across 8 years in three age groups. Front Psychol 2018;9:1-8. Doi:10.3389/fpsyg.2018.00234.

24. Schlarb AA, Reis D, Schröder A. Sleep characteristics, sleep problems, and associations to quality of life among psychotherapists. Sleep Disord 2012;2012:806913. doi: 10.1155/2012/ 806913.

25. Gao X, Ge H, Jiang Y, Lian Y, Zhang C, Liu J. Relationship between job stress and $5-\mathrm{HT} 2 \mathrm{~A}$ receptor polymorphisms on self-reported sleep quality in physicians in Urumqi (Xinjiang, China): A cross sectional study. Int J. Environ Res. Public Health 2018;1034:1-15. Doi:10.3390/ijerph 1505103.

26. Rydstedt LW, Devereux JJ. Psychosocial job strain and sleep quality interaction leading to insufficient recovery. Int $\mathrm{J}$ Environ Res Public Health 2013;10:5863-73; doi:10.3390/ijerph 10115863.

27. Hanson LLM, Leineweber C, Persson V, Hyde M, Heorell T, Westerlund H. Cohort profile: The Swedish Longitudinal Occupational Survey of Health (SLOSH). Int J Epidemiol 2018;691-2i.doi: 10.1093/ije/dyx260.

28. Schiller H, Lekander M, Rajaleid K, et al. The impact of reduced worktime on sleep and perceived stress-a group randomized intervention study using diary data. Scand J Work Environ Health 2017;43:109-16. Doi: 10.5271/sjweh.3610.

29. Ghanbary SA, Ashnagar M, Habibi E, Sadeghi S. Evaluation of rating scale mental effort (RSME) effectiveness for mental workload assessment in nurses. JOHE 2016;5:211-7. DOI:10.18869/ acadpub.johe.5.4.211.

30. Pilz LK, Keller LK, Lenssen D, Roenneberg T. Time to rethink sleep quality: PSQI scores reflect sleep quality on workdays. Sleep J 2018;41:1-8. doi: 10.1093/sleep/zsy029. 